\author{
WALERIAN SANETRA \\ emerytowany profesor Uniwersytetu w Białymstoku
}

\title{
PRAWO PROCESOWE A MATERIALNE PRAWO PRACY. ZAGADNIENIA WYBRANE
}

\begin{abstract}
Abstrakt: Procesowe prawo pracy nie obejmuje całości spraw wynikających ze stosowania materialnego prawa pracy. Zasadniczo ma ono zastosowanie do roszczeń wynikających ze stosunku pracy oraz pewnej grupy spraw rozpoznawanych w trybie nieprocesowym. Wynika to stąd, że w przeszłości odrębna procedura i odrębne sądownictwo pracy tworzone były głównie z myślą o potrzebie wzmocnienia procesowej ochrony interesów pracownika. $Z$ tego powodu ochroną tą nie obejmowano spraw z zakresu zbiorowego prawa pracy, niepracowniczego zatrudnienia czy prawa rynku pracy. Współcześnie istnieje potrzeba umocnienia ustrojowej pozycji sądownictwa pracy oraz rozciągnięcia jego właściwości rzeczowej na całokształt spraw — niezależnie od ich natury prawnej — mieszczących się w granicach materialnego prawa pracy. Wynika to z potrzeby wzmocnienia roli prawa pracy, a także z ciągłej rozbudowy i komplikowania się jego unormowań prawnych, które pociągają za sobą konieczność daleko idącej specjalizacji sędziów oraz ustrojowych i procesowych reguł przez nich stosowanych.
\end{abstract}

Słowa kluczowe: procesowe prawo pracy, materialne prawo pracy, stosunek pracy, zbiorowe prawo pracy, zatrudnienie niepracownicze, prawo rynku pracy

\section{PROCESOWE (FORMALNE) PRAWO PRACY W ZNACZENIU WĘŻSZYM I SZERSZYM}

Procesowe prawo pracy może być pojmowane na dwa sposoby. W wąskim ujęciu opisuje szczególne reguły postępowania przewidziane w kodeksie postępowania cywilnego, które mają zastosowanie w sprawach należących do materialnego prawa pracy. Obejmuje ono zarówno proces, jak i postępowanie nieprocesowe. W szerszej perspektywie do procesowego (formalnego) prawa pracy zaliczyć można także przepisy regulujące ustrój sądów pracy.

Utworzenie przez przepisy ustrojowe odrębnego sądownictwa pracy niejako $\mathrm{z}$ istoty rzeczy prowadzi do ustanowienia, w większym lub mniejszym zakresie, osobnych reguł procesowych modyfikujących ogólne zasady procedury 
sądowej. Tak rzecz miała się w regulacjach ustanawiających sądownictwo pracy w okresie międzywojennym (rozporządzenie Prezydenta RP z 1928 roku i ustawa z 1934 roku) czy w związku z powołaniem do życia okręgowych sądów pracy i ubezpieczeń społecznych (1975) i rejonowych sądów pracy oraz wojewódzkich sądów pracy i ubezpieczeń społecznych (1985) jako jednostek organizacyjnych sądów powszechnych. Warto przy tym podkreślić, że w rozwiązaniach przedwojennych, czyniąc sądy pracy właściwymi w sprawach naruszenia przepisów ustawodawstwa pracy, które przewidywały i przewidują także sankcje karne, powierzono im również rozstrzyganie spraw karnych ${ }^{1}$.

Obecnie, zgodnie z ustawą z dnia 27 lipca 2001 roku — Prawo o ustroju sądów powszechnych ${ }^{2}$, w sądach rejonowych i okręgowych mogą być tworzone wydziały pracy, zaś w sądach apelacyjnych wydziały takie są tworzone (art. $12 \S 1$; art. $16 \S 1$; art. $18 \S 1$ ). Wedle Prawa o ustroju sądów powszechnych wydziały te tworzy się do „spraw z zakresu prawa pracy"; wcześniej używano także określenia „sądy pracy” (sądy ubezpieczeń społecznych, sądy pracy i ubezpieczeń społecznych — w odniesieniu do sądów rejonowych i okręgowych). Zgodnie ze zmienionym art. $262 \S 1$ k.p. sprawy o roszczenia ze stosunku pracy rozstrzygają sądy powszechne zwane „sądami pracy”3. Z przepisów tych wynika, że w sądach powszechnych (rejonowych i okręgowych) nie muszą być tworzone wydziały pracy, co należy rozumieć w ten sposób, że sprawę z zakresu prawa pracy może rozpoznawać wydział cywilny sądu powszechnego. Ważne jest tylko to, by stosował procedurę przewidzianą $\mathrm{w}$ przepisach o postępowaniu odrębnym w sprawach z zakresu prawa pracy. Ponadto, według reguł prawa ustrojowego, nie ma sądów pracy, lecz tylko wydziały pracy. Nazwą ,sądy pracy” posługuje się kodeks pracy i inne ustawy z zakresu prawa pracy, co świadczy o istnieniu sporego zamętu terminologicznego.

Najistotniejsze jednak wydaje się być to, że wprowadzone ostatnio zmiany można interpretować jako wyraz stanowiska polegającego na dążeniu do znoszenia wszelkiego rodzaju odrębności organizacyjnych sądownictwa pracy w ramach struktury sądownictwa powszechnego. W mojej ocenie zmiany ustroju sądów w tym obszarze powinny przebiegać w zupełnie innym kierunku. Wzmocnieniu powinny ulec nie tylko odrębności procesowe w sprawach z szeroko pojętego prawa pracy, ale także sądownictwo pracy w ramach sądownictwa powszechnego - w aspekcie organizacyjnym i funkcjonalnym.

Osobno w tym kontekście należy jeszcze wspomnieć o wprowadzeniu ostatnio (nowelizacja z 16 maja 2019 roku$^{4}$ ) do kodeksu postępowania cywilnego,

${ }^{1}$ Por. A. Dziadzio, Zarys historii sadownictwa pracy, [w:] Procesowe prawo pracy, t. 6, red. K.W. Baran, Warszawa 2016, s. 64 n.

2 Dz.U. z 2020 r. poz. 2072.

3 „Udoskonalenie” terminologiczne wprowadzone przez ustawę z dnia 9 listopada 2017 roku o zmianie niektórych ustaw w celu poprawy terminologicznej systemu prawnego, Dz.U. z 2018 r. poz. 4.

${ }^{4}$ Ustawa o zmianie ustawy - Kodeks pracy oraz niektórych innych ustaw, Dz.U. z 2019 r. poz. 1043 . 
w jego części nieprocesowej, osobnych przepisów w sprawach z zakresu prawa pracy (art. $691^{10}$ n.). Gdyby trzymać się terminologii Prawa o ustroju sądów powszechnych, należałoby stwierdzić, że wnioski w tych sprawach rozpoznawane są w wydziałach pracy sądów powszechnych. Zgodnie zaś z Kodeksem pracy (art. 262 § 1) należałyby one do sądów powszechnych zwanych „sądami pracy”, natomiast zgodnie z nieuchyloną ustawą z 18 kwietnia 1985 roku o rozpoznawaniu przez sądy spraw z zakresu prawa pracy i ubezpieczeń społecznych ${ }^{5}$ mieściłyby się one w kognicji sądów pracy stanowiących odrębne jednostki organizacyjne sądów powszechnych. Z art. 97 i $97^{1}$ k.p. wynika, że w sprawach świadectwa pracy żądanie wnosi się (przysługuje prawo wystąpienia) do sądu pracy, który jest tym sądem tylko z nazwy (art. $262 \S 1$ k.p.) albo jest odrębną jednostką organizacyjną sądu powszechnego (art. 1 ustawy z dnia 18 kwietnia 1985 roku).

\section{SPORY ZE STOSUNKU PRACY A SPORY Z ZAKRESU PRAWA PRACY}

Dla rozważanego tu zagadnienia zasadnicze znaczenie ma zwłaszcza art. 1 k.p.c., art. $459-477^{7}$ k.p.c. oraz określone przepisy ustawy z 2001 roku — Prawo o ustroju sądów powszechnych. Według pierwszego z tych przepisów kodeks postępowania cywilnego normuje między innymi postępowanie w sprawach ze stosunków z zakresu prawa pracy oraz $\mathrm{w}$ innych sprawach, do których przepisy tego kodeksu stosuje się z mocy ustaw szczególnych (sprawy cywilne w znaczeniu procesowym). $\mathrm{W}$ art. 476 k.p.c. zamieszczono natomiast definicję spraw z zakresu prawa pracy. Pojawia się więc pytanie, czy należy identyfikować z sobą takie określenie jak „sprawy ze stosunków z zakresu prawa pracy” ze „sprawami z zakresu prawa pracy". Językowa interpretacja tych zwrotów każe odrzucić taką konkluzję i związać z pierwszym z nich szerszy zakres znaczeniowy aniżeli ten, który wynika z art. 476 k.p.c. Dodać należy, że w terminologii kodeksu postępowania cywilnego, w wyniku nowelizacji z 16 maja 2019 roku, pojęcie ,spraw z zakresu prawa pracy" obejmuje także sprawy rozpoznawane w postępowaniu nieprocesowym, $z$ tym że są to tylko sprawy dotyczące realizacji uprawnienia do otrzymania świadectwa pracy. Skądinąd są to sprawy mieszczące się w pojęciu roszczeń ze stosunku pracy.

Tworzenie osobnych reguł procesowych oraz odrębnego sądownictwa pracy czy systemu organów ich rozpatrywania, najściślej związane jest z ideą ochrony słabszej strony stosunku pracy, a więc pracownika. Innymi słowy, ochronna funkcja prawa pracy powinna znajdować wyraz także w sferze prawa procesowego i związanych z nim rozwiązań z zakresu ustroju organów wymiaru sprawiedliwości. W przeszłości dla rozwiązań tych znamienne było łączenie ochrony

5 Dz.U. z 1985 r. Nr 20, poz. 85 ze zm. 
zasadniczo tylko z roszczeniami ze stosunku pracy i to tylko tymi, które były wnoszone przez pracownika, a nie pracodawcę. Odrębne sądownictwo i procedura mają jednak także - i to współcześnie jest ważniejsze — swoje źródło w potrzebie specjalizacji organów wymiaru sprawiedliwości wynikającej ze złożoności, skomplikowania i obszerności unormowań prawa pracy.

W myśl art. 476 § 1 przez sprawy z zakresu prawa pracy rozumie się sprawy: 1. o roszczenia ze stosunku pracy lub z nim związane; 2. o ustalenie istnienia stosunku pracy, jeżeli łączący strony stosunek prawny — wbrew zawartej między nimi umowie - ma cechy stosunku pracy; 3. o roszczenia z innych stosunków prawnych, do których, z mocy odrębnych przepisów, stosuje się przepisy prawa pracy; 4. o odszkodowania dochodzone od pracodawcy na podstawie przepisów o świadczeniach z tytułu wypadków przy pracy i chorób zawodowych. Do tego przepisu nasuwają się jednak pewne uwagi. Po pierwsze, przepis ten w sposób szczególny i wąski definiuje kategorię spraw z zakresu prawa pracy. Po drugie, jest to definicja na użytek określenia przedmiotu jednego z postępowań odrębnych i w tym sensie definicja formalna (spraw z zakresu prawa pracy w znaczeniu procesowym - art. 1 k.p.c.). Po trzecie, nie ma ona zastosowania do trybu nieprocesowego, a w tym trybie, $\mathrm{z}$ mocy ustaw szczególnych, rozpoznawane są różnego rodzaju sprawy z zakresu prawa pracy $\mathrm{w}$ znaczeniu materialnym (jako sprawy cywilne - art. 1 k.p.c.). Po czwarte, w przepisie tym wymieniono kategorie spraw, co ułatwia ich identyfikację, ale jednocześnie nie oznacza, że ujęcie to jest precyzyjne i wykluczające różnego rodzaju wątpliwości interpretacyjne. Po piąte, określenie „roszczenia ze stosunku pracy i z nim związane” nasuwa pewną analogię do dość często spotykanego sposobu określania przedmiotu prawa pracy, jako stosunku pracy i stosunków prawnych z nim związanych; płynąca stąd sugestia, że w sensie procesowym sprawy z zakresu prawa pracy, to po prostu sprawy należące do przedmiotu prawa pracy, jest wszakże myląca. Po szóste, w przepisie tym wyraźnie odsyła się do pojęcia „przepisów prawa pracy” w odniesieniu do „,innych stosunków prawnych”, do których się je stosuje.

\section{PROCESOWE PRAWO PRACY A ZBIOROWE PRAWO PRACY}

Prawo pracy współcześnie dzielone jest na indywidualne i zbiorowe prawo pracy. Pierwsze z nich to zasadniczo prawo stosunku pracy, przy czym spory sądowe powstające na jego tle, zasadniczo rozstrzygane są przez sądy pracy jako „sprawy z zakresu prawa pracy”. Inaczej sprawa ma się ze sprawami powstającymi w związku ze stosowaniem i przestrzeganiem zbiorowego prawa pracy, gdyż nie mieszczą się one w pojęciu ,spraw z zakresu prawa pracy” z art. $476 \S 1$ k.p.c. Nie oznacza to jednakże, że nie ma możliwości i potrzeby poddania niektórych spraw wynikających z funkcjonowania przepisów zbiorowego prawa pracy sądownictwu pracy, przy czym można i należy mówić tu o tendencji do poszerzania 
się kognicji sądów pracy w tym zakresie ${ }^{6}$. Dotyczy to przypadków, w których przepisy te w pewnym sensie współkształtują sytuację prawną stron stosunku pracy, np. pracowników pełniących funkcje w związkach zawodowych czy uczestniczących w strajku, który ma charakter nielegalny. Ponadto szereg spraw z zakresu zbiorowego prawa pracy przekazywana jest do załatwienia w trybie postępowań nieprocesowych, które z reguły toczą się przed sądami pracy. Tak jest w przypadku rejestracji układów zbiorowych pracy i ich wykreślenia z rejestru, stwierdzenia reprezentatywności związku zawodowego; reprezentatywność ponadzakładowej organizacji związkowej obecnie stwierdza sąd okręgowy a reprezentatywność zakładowej organizacji związkowej sąd rejonowy — sąd pracy.

Osobno należy wspomnieć o sprawach z zakresu przepisów o przedsiębiorstwach państwowych i o samorządzie załogi przedsiębiorstwa państwowego. Są one rozpoznawane w postępowaniu nieprocesowym (art. 691 n. k.p.c.) przez sądy okręgowe. W mojej ocenie stosunki, i tym samym spory, między radą pracowniczą a dyrektorem przedsiębiorstwa państwowego należą do przedmiotu zbiorowego prawa pracy. Nie są one poddane sądownictwu pracy, choć rozpoznawane są zgodnie z - do pewnego stopnia odrębnymi - regułami postępowania nieprocesowego $^{7}$. Ważne jest przy tym to, że do zasad tych, w sprawach dotyczących tajemnicy przedsiębiorstwa (informacji przekazywanych przedstawicielstwu pracownicze$\mathrm{mu}$ ), odsyłają przepisy ustaw normujących udział pracowników w zarządzaniu zawarte na przykład w ustawie z dnia 7 kwietnia 2006 roku o informowaniu pracowników i przeprowadzaniu z nimi konsultacji (o radach pracowników) ${ }^{8}$. Są to przepisy, które należy kwalifikować jako regulacje należące do zbiorowego prawa pracy, choć przekazują rozstrzyganie wspomnianych sporów (w trybie nieprocesowym) do sądów rejonowych — sądów gospodarczych. Mamy tu więc przykład na to, że sprawy w sensie materialnoprawnym należące do prawa pracy, mogą być rozpatrywane także przez sądy gospodarcze.

Jeszcze wyraźniej taka natura sporu uwidacznia się w przypadku unormowanym w art. 8 ust. 3 ustawy z dnia 4 marca 1994 roku o zakładowym funduszu świadczeń socjalnych ${ }^{9}$. Według zawartych tam zapisów związkom zawodowym przysługujeprawo wystąpienia do sądu pracy z roszczeniem o zwrot funduszowi świadczeń socjalnych środków wydatkowanych niezgodnie z przepisami ustawy lub o przekazanie należnych środków na ten fundusz. Roszczenia tego typu nie mieszczą się w pojęciu sprawy indywidualnego stosunku pracy (art. 7 ust. 2 usta-

${ }^{6}$ Por. W. Sanetra: Sądy wobec sporów z zakresu zbiorowego prawa pracy, [w:] Zbiorowe prawo pracy w społecznej gospodarce rynkowej, red. G. Goździwicz, Torun 2000, s. 271 n.; idem, Reprezentacja związowa praw i interesów pracowniczych $w$ sporach ze stosunku pracy, [w:] Reprezentacja praw i interesów pracowniczych, red G. Goździewicz, Torun 2001, s. 283 n.; idem, W sprawie spraw z zakresu prawa pracy, [w:] Zagadnienia prawa pracy i prawa socjalnego. Ksiegga jubileuszowa Profesora Herberta Szurgacza, red. Z. Kubot, T. Kuczyński, Warszawa 2011, s. 206-211.

7 Nieco szerzej na ten temat por. W. Sanetra, W sprawie spraw z zakresu..., s. 207-208.

8 Dz.U. z 2006 r. Nr 79, poz. 550 ze zm.

9 Dz.U. z 1996 r. Nr 70, poz. 335 ze zm. 
wy z dnia 23 maja 1991 roku o związkach zawodowych ${ }^{10}$ ). Są to sprawy z zakresu zbiorowych praw i interesów pracowników i w sensie ogólnoteoretycznym mogą być traktowane jako rodzaj spraw z zakresu zbiorowego prawa pracy oraz odmiana sporu zbiorowego, jakkolwiek, w aspekcie procesowym, spór ma charakter indywidualny, gdyż toczy się przed sądem między pracodawcą a związkiem zawodowym. W sensie procesowym związek zawodowy działa we własnym imieniu, a nie w imieniu, czy na rzecz pracowników (nie wytacza na ich rzecz powództwa). Natomiast w sensie ogólniejszym, działanie związku zawodowego w ramach kompetencji wynikającej z art. 8 ust. 3 ustawy ozakładowym funduszu świadczeń socjalnych ma oczywiście uzasadnienie $\mathrm{w}$ istnieniu określonego interesu pracowników, którym akcja związkowa przed sądem pracy ma służyć i o tyle jest uzasadniona, jeżeli do tego celu zmierza. Mimo że — w mojej ocenie — nie ma podstaw, w przypadku wskazanego powództwa związku zawodowego, do sięgnięcia do art. $476 \S 1$ pkt 1 k.p.c. ani do art. $476 \S 1$ pkt 2 k.p.c., to jednak w orzecznictwie sądowym przyjęto, że sąd pracy powinien sprawę rozstrzygać $\mathrm{w}$ trybie przepisów o postępowaniu odrębnym w sprawach z zakresu prawa pracy ${ }^{11}$. Sprawą niejasną jest czy i jak dalece może on do związku zawodowego, jako strony powodowej, stosować odpowiednio przepisy odnoszące się do pracownika w sprawach z zakresu prawa pracy.

\section{ROSZCZENIA ZE STOSUNKÓW NIEPRACOWNICZEGO ZATRUDNIENIA}

Do przedmiotu prawa pracy, obok stosunku pracy (indywidualne prawo pracy), zaliczane są zwłaszcza takie stosunki prawne jak: stosunki zbiorowego prawa pracy (w tym spory zbiorowe i konflikty organizacyjne), stosunki poprzedzające nawiązanie stosunku pracy (przygotowujące nawiązanie stosunku pracy, stosunki zatrudnienia i bezrobocia, stosunki rynku pracy, prawo rynku pracy), niepracownicze stosunki prawa pracy (niepracownicze zatrudnienie), administracyjne stosunki prawa pracy, stosunki z zakresu osobowego prawa pracy, z zakresu karnego prawa pracy, normodawcze stosunki prawa pracy oraz procesowe stosunki prawa pracy (procesowe prawo pracy). W niniejszych rozważaniach zasadnicze znaczenie ma odróżnienie procesowego prawa pracy (reguł rozstrzygania zwłaszcza spraw spornych) od materialnego prawa pracy, a więc zasadniczo prawa określającego prawa, obowiązki i odpowiedzialność poza ramami postępowania sądowego czy quasi-sądowego prowadzonego w trybie procesowym, nieprocesowym, zabezpieczającym i egzekucyjnym. $\mathrm{Z}$ uwagi na ograniczone ramy niniejszego opracowa-

10 Dz.U. z 1991 r. Nr 55, poz. 234 ze zm.

11 Por. A.M. Świątkowski, Kognicja sądów pracy, [w:] System prawa pracy, t. 6. Procesowe prawo pracy, red. K.W. Baran, Warszawa 2016, s. 340-342. 
nia uwzględnione zostały w nim tylko niektóre, wybrane regulacje materialnego prawa pracy, głównie takie, które do tej pory nie były zauważane bądź też raczej słabo dostrzegane i analizowane. Dotyczy to między innymi niepracowniczego zatrudnienia.

Niepracownicze stosunki zatrudnienia dzieli się na ogół na niepracownicze zatrudnienie typu cywilnoprawnego, niepracownicze zatrudnienie typu administracyjnoprawnego, niepracownicze zatrudnienie typu penalnego i niepracownicze zatrudnienie typu ustrojowego ${ }^{12}$. Ich zasadniczą cechą jest to, że w ich ramach wykonywane jest, w mniejszym lub większym stopniu, odpłatne zatrudnienie (praca), choć nie spełniają one przesłanek umożliwiających uznanie go za zatrudnienie pracownicze ( $\mathrm{w}$ ramach stosunku pracy).

W ostatnich latach, w następstwie nasilania się zjawiska zatrudniania na szeroką skalę osób na podstawie umów zlecenia, umów o świadczenie usług, do których stosuje się przepisy o zleceniu oraz umów o dzieło, obserwujemy reakcję ze strony ustawodawcy polegającą na coraz częstszym stosowaniu do tego zatrudnienia przepisów prawa pracy. Przykładem jest dokonana w 2016 roku nowelizacja ustawy z dnia 10 października 2002 roku o minimalnym wynagrodzeniu za pracę ${ }^{13}$. Wprowadzono w niej tak zwaną minimalną stawkę godzinową, która oznacza minimalną wysokość wynagrodzenia za każdą godzinę wykonania zlecenia lub świadczenia usług. Trudno uznać, że nie jest to unormowanie z zakresu prawa pracy i że stanowi ono część prawa cywilnego. Mamy tu bowiem do czynienia z łączną (wspólną) regulacją minimalnego wynagrodzenia pracownika, zleceniobiorcy oraz osoby świadczącej usługi, choć w tym drugim przypadku ustawa operuje osobno zdefiniowanym pojęciem ,minimalnej stawki godzinowej”. Skoro tak, to przepisy dotyczące minimalnej stawki godzinowej są przepisami prawa pracy w pojęciu art. $476 \S 1$ pkt 2 k.p.c. Należy więc uznać, że spory o roszczenia dotyczące minimalnej stawki godzinowej, choć nie są sporami o roszczenia ze stosunku pracy ani o roszczenia związane z tym stosunkiem, należą do właściwości sądów pracy. Trzeba jednak zaznaczyć, że powyższe twierdzenie nie odpowiada w pełni literze wskazanego przepisu. Mowa w nim bowiem o roszczeniach „do których z mocy odrębnych przepisów stosuje się przepisy prawa pracy”, natomiast w ustawie z 10 października 2002 roku o minimalnym wynagrodzeniu za pracę brak jest sformułowania, że przepisy dotyczące minimalnego wynagrodzenia stosuje się także do roszczeń ze zlecenia i świadczenia usług. Należy przyjąć, że sąd pracy jest właściwy w sprawach roszczeń o minimalną stawkę godzinową i jej wysokość, natomiast nie należą do niego kwestie inne, wynikające z zawarcia umowy zlecenia czy umowy o świadczenie usług.

12 Por. W. Sanetra: Prawo pracy. Zarys wyktadu, t. 1, Białystok 1994, s. 54 n. Więcej rodzajów stosunków niepracowniczego zatrudnienia zostało wyodrębnionych i omówionych w: System Prawa Pracy, t. 7, [w:] Zatrudnienie niepracownicze, red. K.W. Baran, Warszawa 2015.

13 Dz.U. z 2018 r. poz. 2177 ze zm. 
W przeszłości, do stosunków niepracowniczego zatrudnienia o charakterze administracyjnoprawnym, należały stosunki służbowe nawiązywane w służbie publicznej na podstawie mianowania. Obecnie także stosunki zatrudnienia nawiązywane w aparacie publicznym na podstawie mianowania są stosunkami pracy i stąd roszczenia z tych stosunków mieszcząsię w pojęciu „spraw z zakresu prawa pracy" w rozumieniu art. $476 \S 1$ k.p.c. i wobec tego rozpoznawane są przez sądy pracy. Wyjątek stanowią sprawy ze stosunków prawnych osób zatrudnionych w służbach zmilitaryzowanych (mundurowych, zbrojnych), które są stosunkami niepracowniczego zatrudnienia o charakterze administracyjnoprawnym. Roszczenia, które z nich wynikają, nie są roszczeniami, „,o których z mocy odrębnych przepisów stosuje sięprzepisy prawa pracy" (art. $476 \S 1$ pkt 2 k.p.c.), jakkolwiek - co najmniej w teorii prawa pracy i w jego dydaktyce — pragmatyki służb zmilitaryzowanych, w części dotyczącej zatrudnienia funkcjonariuszy tych służb, zaliczane są do regulacji prawa pracy. Przyjęło się natomiast uważać, że zasadniczo nie są to te przepisy prawa pracy, o których mowa w art. $476 \S 1 \mathrm{pkt} 2$ k.p.c., chyba że jakaś pragmatyka, w odniesieniu do niektórych instytucji zatrudnienia, wyraźnie odsyła do przepisów prawa pracy (na przykład w sprawie ochrony rodzicielstwa, sprawy niektórych urlopów, ochrony uposażenia). Do pewnego stopnia potwierdzają to też te unormowania pragmatyk służb zmilitaryzowanych, które w przypadku niektórych rodzajów spraw, wyraźnie (w sposób ogólny bądź konkretny - przez wymienienie rodzaju spraw) przewidują drogę sądownictwa pracy, jako sposobu ich załatwiania ${ }^{14}$. W pozostałych sprawach właściwe są sądy administracyjne. Rozwiązanie takie może wszakże budzić wątpliwości jeżeli zważyć, że zgodnie z Konstytucją RP (art. 176 ust. 2) istnieje domniemanie drogi sądownictwa powszechnego a sądy administracyjne powołane są do sprawowania kontroli działalności administracji publicznej (art. 184 Konstytucji RP) ${ }^{15}$.

Osobną kategorię niepracowniczego zatrudnienia stanowią stosunki niepracowniczego zatrudnienia o charakterze penalnym. Związane jest to z ogólniejszym zjawiskiem wykorzystywania w polityce karnej pracy, jako jednego z instrumentów zwalczania przestępczości i reedukacji skazanych. Oprócz tego prawo karne (kodeks karny, kodeks wykroczeń) pełni rolę środka wymuszania przestrzegania przepisów prawa pracy, polegającego na ustanowieniu odpowiedzialności za wykroczenia i przestępstwa przeciwko prawom pracownika (pracy zarobkowej). Jeżeli chodzi o niepracownicze zatrudnienie typu penalnego, to na szczególną uwagę zasługują stosunki zatrudnienia więźniów na podstawie skierowania ich

14 Por. T. Kuczyński, Kompetencje sadów administracyjnych $w$ sporach dotyczacych zatrudniania, [w:] System prawa pracy. Procesowe prawo pracy, s. 392; idem, Właściwość sadów administracyjnych w sprawach stosunków stużbowych, Wrocław 2000, s. $133 \mathrm{n}$.

15 Por. W. Sanetra, Ustrój sądów a rozstrzyganie spraw z zakresu prawa pracy i ubezpieczeń społecznych, [w:] „Przegląd Sądowy” 2009, nr 9 (11), s. 5 n.; idem, Właściwość sądów powszechnych (sądów pracy $i$ ubezpieczeń społecznych) $i$ sądów administracyjnych $w$ sprawach z zakresu ubezpieczeń społecznych, [w:] Aktualne problemy rozgraniczenia właściwości sądów administracyjnych i powszechnych, red. M. Błahucki, T. Górzyńska, Warszawa 2011, s. 71 n.

Przegląd Prawa i Administracji 124, 2021

(C) for this edition by CNS 
do pracy przez dyrektora zakładu karnego. W tym przypadku więzień nie ma statusu pracownika, wykonawcy pracy nakładczej, zleceniobiorcy, wykonawcy dzieła (a także osoby wykonującej pracę na innej podstawie). Tego rodzaju formy zatrudnienia więźniów wyraźnie przewiduje kodeks karny wykonawczy. Stosunek zatrudnienia ma charakter publicznoprawny ale różny od typowego stosunku administracyjnoprawnego i stąd określany jest jako stosunek o naturze penalnej. Do stosunku tego nie stosuje się przepisów prawa pracy, z wyjątkiem przepisów o czasie pracy i bezpieczeństwie i higienie pracy (art. $121 \S 9$ k.k.w.). Dość zagadkowo brzmi przepis, który stanowi, że do „skazanych pracujących”, w zakresie nieuregulowanym w Kodeksie karnym wykonawczym, stosuje się przepisy prawa pracy. Gdyby unormowanie to rozumieć literalnie to należałoby na przykład uznać, że przepisy prawa pracy, w odniesieniu do więźniów, w całości stosuje się do umów o dzieło.

$\mathrm{Z}$ mocy art. 121 k.k.w. do stosunków prawnych wynikających ze skierowania więźnia do pracy przez dyrektora zakładu karnego stosuje się przepisy o czasie pracy i o bezpieczeństwie i higienie pracy. Oznacza to tym samym, że roszczenia wynikające $\mathrm{z}$ zastosowania tych przepisów są roszczeniami z zakresu prawa pracy w pojęciu art. $476 \S 1$ pkt 2 k.p.c. i wobec tego należą do właściwości sądów pracy. W tym przypadku mamy do czynienia $\mathrm{z}$ roszczeniem wynikającym ze stosunku prawnego o charakterze publicznoprawnym (penalnym), a nie zobowiązaniowym, co jest znamienne dla stosunków niepracowniczego zatrudnienia o naturze cywilnoprawnej. Problem stanowi kwestia dochodzenia innych roszczeń, w tym zwłaszcza o wynagrodzenie za pracę, tym bardziej, że kodeks karny wykonawczy gwarantuje skazanym (w tym zatrudnionym na podstawie skierowania) minimalne wynagrodzenie. W mojej ocenie kontrola prawidłowości tego typu roszczeń powinna być przekazana sądom pracy.

Stosunki niepracowniczego zatrudnienia to także stosunki prawne o charakterze ustrojowym, których szczególnie istotnym przykładem są stosunki wykonywania mandatu przez posłów i senatorów. W myśl ustawy z dnia 9 maja 1996 roku o wykonywaniu mandatu posła i senatora ${ }^{16}$ są oni pracodawcami względem zatrudnionych $\mathrm{w}$ ich biurach pracowników i w związku z tym, w tym charakterze mogą wstępować w sporach przed sądami pracy (jako pozwani i pozywający). Z Sejmem lub Senatem nie łączą ich stosunki pracy, choć bywa nieraz wypowiadane zdanie przeciwne. Ich zatrudnienie nie ma charakteru administracyjnoprawnego, bo Sejm (Senat) nie jest organem administracji publicznej w pojęciu art. 184 Konstytucji RP, co wyklucza administracyjną drogę sądową. Pozostaje więc droga sądownictwa powszechnego, w tym sądownictwa pracy, bo przecież nie można uznać, że posłowie i senatorowie pozbawieni są prawa do sądu (art. 45 Konstytucji $\mathrm{RP}$ ). Zgodnie $\mathrm{z}$ art. 27 ustawy o wykonywaniu mandatu posła i senatora uposażenie posła (senatora), wraz z dodatkami, jest traktowane jako wynagrodzenie ze stosunku pracy. Oznacza to, że roszczenia z tego tytułu mogą być dochodzone

16 Dz.U. z 2018 r. poz. 1799. 
przed sądem pracy jako roszczenia ze stosunku pracy (art. $476 \S 1$ pkt 1 k.p.c.), a nie jako roszczenia ze stosunku prawnego, do którego niejako pomocniczo stosuje się przepisy prawa pracy (art. $476 \S 1$ pkt 2 k.p.c.).

\section{W STRONĘ POSZERZENIA WŁAŚCIWOŚCI RZECZOWEJ ORAZ ODRĘBNOŚCI SĄDOWNICTWA PRACY}

$\mathrm{Z}$ upływem lat obserwujemy stopniowe poszerzanie się zakresu kognicji sądów pracy. Związane jest to $\mathrm{z}$ mnożeniem i komplikowaniem się unormowań materialnego prawa pracy, ale nie tylko. Zakres tej kognicji poszerzony został zwłaszcza w ramach reformy sądownictwa pracy w 1985 roku (związane to było z wprowadzeniem procesowej definicji ,spraw z zakresu prawa pracy”), ale niejako za cenę likwidacji komisji rozjemczych i komisji odwoławczych do spraw pra$\mathrm{cy}^{17}$. Z biegiem lat obserwujemy także zjawisko „liberalnego”, rozszerzającego interpretowania formuły ,roszczeń związanych z roszczeniami ze stosunku pracy” (art. $476 \S 1$ pkt 1 k.p.c.) oraz roszczeń, „,do których z mocy odrębnych przepisów stosuje się przepisy prawa pracy”( art. $476 \S 1$ pkt 2 k.p.c.). Z czasem rośnie też liczba „odrębnych przepisów”, do których odnosi się art. $476 \S 1$ pkt 2 k.p.c. Obok aktów normatywnych, w których pojawia się odesłanie ustawowe do „przepisów prawa pracy", co oznacza automatycznie objęcie kognicją sądów pracy kolejnych rodzajów roszczeń, ciągle ustanawiane są także nowe przepisy, w których stwierdza się wprost lub pośrednio, że w sprawach tych roszczeń właściwe są sądy pracy. Wspomnieć tu można o przepisie art. 112 § 2 k.p., przewidującym możliwość wystąpienia do sądu pracy o uchylenie kary porządkowej, czy o art. 97 i 97 k.p. dotyczącym świadectwa pracy, o art. 8 ust. 2 ustawy o zakładowym funduszu świadczeń socjalnych również jednoznacznie wskazującym na kognicję sądu pracy. Innego przykładu dostarcza art. 20 ust. 2 ustawy z dnia 13 lipca 2006 roku o ochronie roszczeń $\mathrm{w}$ razie niewypłacalności pracodawcy ${ }^{18}$, który stanowi, że spory powstałe $\mathrm{w}$ związku $\mathrm{z}$ odmową wypłaty świadczeń rozstrzyga sąd właściwy w sprawach z zakresu prawa pracy, co należy rozumieć w ten sposób, że jest to sąd pracy orzekający w trybie postępowania odrębnego w sprawach z zakresu prawa pracy; procesowa pozycja pracownika przypada tu świadczeniobiorcy.

Ustanawianie odrębnego sądownictwa pracy oraz odrębnych reguł postępowania cywilnego (procesowego prawa pracy) uzasadnione jest dwojakiego rodzaju racjami. Jedna z nich to konieczność wzmocnienia w procesie cywilnym pozycji pracownika, jako słabszej strony stosunku pracy. Druga natomiast, to konieczność daleko idącej specjalizacji w stosowaniu przez sądy materialnego prawa pracy.

\footnotetext{
17 Por. W. Sanetra, W sprawie spraw..., s. $199 \mathrm{n}$.

18 Dz.U. z 2020 r. poz. 7.
} 
Znajomość i praktyczne opanowanie mechanizmów działania tego prawa jest coraz trudniejsze i w związku z tym wymaga coraz dalej posuniętej specjalizacji. Zmusza sędziów do nieustannego poszerzania i pogłębiania praktycznej i teoretycznej znajomości prawa pracy. W moim przekonaniu uzasadnia to jednocześnie potrzebę organizacyjnego umocnienia sądownictwa pracy, przy jednoczesnym radykalnym poszerzeniu zakresu jego kognicji. W ujęciu procesowym do kategorii spraw z zakresu prawa pracy powinny więc zostać zaliczone nie tylko sprawy roszczeń powstających na tle stosowania indywidualnego prawa pracy, ale także sprawy z zakresu zbiorowego prawa pracy i tej części stosunków administracyjnych prawa pracy, w tym stosunków niepracowniczego zatrudnienia, które zaliczane są do prawa pracy. W zakresie kognicji sądów pracy w szerszym zakresie powinny znaleźć się także sprawy z zakresu prawa rynku pracy i innych stosunków poprzedzających nawiązanie stosunku pracy, a także przekazać należałoby im sprawy wykroczeń przeciwko prawom pracownika. Utrzymania wymaga przy tym połączenie spraw z zakresu prawa pracy ze sprawami z zakresu ubezpieczeń społecznych. Do rozważania jest tu ponadto skierowanie do sądów pracy i ubezpieczeń społecznych także spraw z zakresu prawa socjalnego (poza ubezpieczeniami społecznymi, bo te de lege lata rozstrzygane są przez sądy pracy i ubezpieczeń społecznych).

\section{PROCEDURAL LAW AND SUBSTANTIVE LABOUR LAW}

\section{Summary}

Procedural labour law does not cover all matters arising from the application of substantive labour law. In principle, it applies to claims arising from employment relationship and to a certain group of cases considered in a no-trial procedure. This is due to the fact that in the past a separate procedure and separate judiciary were created mainly with a view to strengthening the procedural protection of employee interests. For this reason, the protection did not extend to collective labour law, non-employee employment, and labour market law. Nowadays, there is a need to strengthen the systemic position of the labour judiciary and to extend its substantive jurisdiction to all cases - regardless of their legal nature - within the limits of substantive law. This is due to the need to strengthen the role of labour law as well as the continuous expansion and complexity of its legal regulations which entail the need for far-reaching specialization of judges as well as the system and procedural rules they apply.

Keywords: procedural labour law, material labour law, employment relationship, collective labour law, non-employee employment, labour market law 


\section{BIBLIOGRAFIA}

Baran K.W., System Prawa Pracy, t. 7. Zatrudnienie niepracownicze, Warszawa 2015.

Dziadzio A., Zarys historii sadownictwa pracy, [w:] System Prawa Pracy, t. 6. Procesowe prawo pracy, red. K.W. Baran, Warszawa 2016.

Kuczyński T., Kompetencje sądów administracyjnych w sporach dotyczących zatrudniania, [w:] System Prawa Pracy, t. 6. Procesowe prawo pracy, red. K.W. Baran, Warszawa 2016.

Kuczyński T., Właściwość sądów administracyjnych w sprawach stosunków służbowych, Wrocław 2000.

Sanetra W., Prawo pracy. Zarys wyktadu, t. 1, Białystok 1994.

Sanetra W., Reprezentacja zwiazkowa praw i interesów pracowniczych $w$ sporach ze stosunku pracy, [w:] Reprezentacja praw i interesów pracowniczych, red. G. Goździewicz, Toruń 2001.

Sanetra W., Sąy wobec sporów z zakresu zbiorowego prawa pracy, [w:] Zbiorowe prawo pracy w społecznej gospodarce rynkowej, red. G. Goździewicz, Torun 2000.

Sanetra W., Ustrój sądów a rozstrzyganie spraw z zakresu prawa pracy i ubezpieczeń społecznych, „Przegląd Sądowy” 2011, nr 9.

Sanetra W., Właściwość sądów powszechnych (sadów pracy i ubezpieczeń społecznych) i sądów administracyjnych $w$ sprawach z zakresu ubezpieczeń spotecznych, [w:] Aktualne problemy rozgraniczenia właściwości sąów administracyjnych i powszechnych, red. M. Błachucki, T. Górzyńska, Warszawa 2011.

Sanetra W., W sprawie spraw z zakresu prawa pracy, [w:] Zagadnienia prawa pracy i prawa socjalnego. Ksiega jubileuszowa Profesora Herberta Szurgacza, red. Z. Kubot, T. Kuczyński, Warszawa 2011.

Świątkowski A.M., Kognicja sąów pracy, [w:] System Prawa Pracy, t. 6. Procesowe prawo pracy, red. K.W. Baran, Warszawa 2016. 